\title{
The Unknown Unknowns: Recovering Gamma-Delta T Cells for Control of Human Immunodeficiency Virus (HIV)
}

\author{
Shivkumar Biradar ${ }^{1}$, Michael T. Lotze ${ }^{2}$ and Robbie B. Mailliard ${ }^{1, *(1)}$ \\ 1 Department of Infectious Diseases and Microbiology, University of Pittsburgh, Pittsburgh, PA 15261, USA; \\ SSB38@pitt.edu \\ 2 Departments of Surgery, Immunology, and Bioengineering, University of Pittsburgh, \\ Pittsburgh, PA 15261, USA; lotzemt@upmc.edu \\ * Correspondence: rbm19@pitt.edu
}

Academic Editors: Clare Jolly and Philip Tedbury

Received: 5 November 2020; Accepted: 15 December 2020; Published: 17 December 2020

\begin{abstract}
Recent advances in $\gamma \delta \mathrm{T}$ cell biology have focused on the unique attributes of these cells and their role in regulating innate and adaptive immunity, promoting tissue homeostasis, and providing resistance to various disorders. Numerous bacterial and viral pathogens, including human immunodeficiency virus-1 (HIV), greatly alter the composition of $\gamma \delta \mathrm{T}$ cells in vivo. Despite the effectiveness of antiretroviral therapy (ART) in controlling HIV and restoring health in those affected, $\gamma \delta$ T cells are dramatically impacted during HIV infection and fail to reconstitute to normal levels in HIV-infected individuals during ART for reasons that are not clearly understood. Importantly, their role in controlling HIV infection, and the implications of their failure to rebound during ART are also largely unknown and understudied. Here, we review important aspects of human $\gamma \delta \mathrm{T}$ cell biology, the effector and immunomodulatory properties of these cells, their prevalence and function in HIV, and their immunotherapeutic potential.
\end{abstract}

Keywords: gamma delta T cell; V 22 ; V81; HIV; immunotherapy

Reports that say that something hasn't happened are always interesting to me, because as we know, there are known knowns; there are things we know we know. We also know there are known unknowns; that is to say we know there are some things we do not know. But there are also unknown unknowns - the ones we don't know we don't know. And if one looks throughout the history of our country and other free countries, it is the latter category that tends to be the difficult ones. United States Secretary of Defense Donald Rumsfeld; 12 February 2002.

\section{Introduction}

Although conventional alpha-beta $(\alpha \beta)$ T cells have been studied intensively as a current "known" in the field of immunology, with the basis of their recognition of processed peptides in the context of MHC molecules being well-understood, far less attention has been paid to gamma delta $(\gamma \delta) \mathrm{T}$ cells. This, is in part due to their relatively limited numbers in the blood and spleen, and because they reside primarily in tissues less readily accessible for study. They have important early innate immune functions, recognizing relatively conserved pathogen-associated molecules, simple metabolites, and stress ligands expressed on infected and transformed cells. They can mount rapid and direct cytolytic responses while producing cytokines and chemokines to promote the function and mobilization of other immune effector cells [1]. They are widely distributed throughout the body [2], particularly within epithelial sites, and have the capability to recognize a variety of self-, as well as non-self-antigens without regard 
to MHC constraint. Their prospective utilization or strategic targeting in novel immunotherapeutic approaches to treat a variety of chronic diseases is quite attractive. This is especially true in instances where classical $\alpha \beta \mathrm{T}$ cell immune escape may be of particular concern. However, because their frequency and function can be severely altered in the setting of diseases such as HIV, and because there are still so many "unknowns" regarding the basic biology of $\gamma \delta$ T cells in health and disease, there are hurdles to be addressed before their therapeutic potential can be fully appreciated. In this review, we trace some of the current progress in studies related to $\gamma \delta \mathrm{T}$ cell biology as we explore their function, particularly in the setting of chronic HIV infection, and discuss their potential for therapeutic application.

\section{Phenotypic and Functional Subsets of $\gamma \delta$ T Cells}

Based on TCR $\delta$ chain usage, human $\gamma \delta \mathrm{T}$ cells can be categorized into three major subsets: $\mathrm{V} \delta 1, \mathrm{~V} \delta 2$, and V $\delta 3 \mathrm{~T}$ cells. V $\delta 1 \mathrm{~T}$ cells constitute less than $30 \%$ of total $\gamma \delta \mathrm{T}$ cells in the peripheral blood, but they are the predominant population in tissues, including the dermis, spleen, liver, gut epithelia, lung, and other mucosal sites [3]. V $81 \mathrm{~T}$ cells maintain epithelial tissue integrity, expressing classical rearranged receptors that are selected in the thymus, and function in part through recognition of the stress-inducible ligands MICA and MICB expressed by virus-infected and transformed cells, and self-glycolipids presented by CD1c/d molecules (Table 1) [4]. V $\gamma 9 \mathrm{~V} \delta 2 \mathrm{~T}$ cells circulating in the peripheral blood and lymphatics recognize phosphoantigens produced by various microbes and transformed host cells in an MHC non-dependent fashion [1]. The third subtype of $\gamma \delta \mathrm{T}$ cells, the V $\delta 3$ $\mathrm{T}$ cells, comprise approximately $0.6 \%$ of peripheral blood $\mathrm{T}$ lymphocytes, and are also found in the liver and gut (Table 1) [5,6]. Although there are no known antigens specifically identified in association with V83 T cell receptor recognition, activation of this cell type has been shown to occur through their cognate interactions with MHC-class I as well as CD1d [7], an MHC-like molecule capable of presenting lipid moieties. The frequency of V $83 \mathrm{~T}$ cells is often expanded in the peripheral blood of renal and stem cell transplant recipients with cytomegalovirus reactivation [8], and in those with B cell chronic lymphocytic leukemia [9]. Similar to V $82 \mathrm{~T}$ cells, V $83 \mathrm{~T}$ cells can also act as a bridge, linking innate and adaptive branches of immunity through their modulation of B cell and dendritic cell (DC) function $[10,11]$. Furthermore, V $\delta 4, V \delta 6, V \delta 7$, and V $\delta 8 \mathrm{~T}$ cells have been detected in the peripheral blood of lymphoma patients, serving as distinct minority subsets of $\gamma \delta \mathrm{T}$ cells, but their chain pairing and activation mechanisms remain unclear [12].

Table 1. Distribution and function of $\gamma \delta$ subtypes.

\begin{tabular}{|c|c|c|c|}
\hline$\gamma \delta$ Subtypes & V81 & $\mathrm{V} \delta 2$ & V83 \\
\hline Distribution & $\begin{array}{l}\text { Dermis, spleen, liver, gut } \\
\text { epithelia, lung, peripheral } \\
\text { blood, and other mucosal } \\
\text { sites }\end{array}$ & Peripheral blood and lymphatics & Peripheral blood, liver, and gut \\
\hline Function & $\begin{array}{l}\text { Maintain epithelial tissue } \\
\text { integrity by recognizing } \\
\text { stress-induced MICA/B [4] } \\
\text { Major source of IL-17 [14] } \\
\text { Lyse autologous tumor [15] } \\
\text { Opsonization of CMV } \\
\text { through CD16 induce IFN- } \gamma \\
\text { response [16]. } \\
\text { Cytotoxicity against HIV } \\
\text { infected cells through } \\
\text { NKG2C triggering [17]. } \\
\text { Recognize lipid antigens } \\
\text { presented by CD1d [4]. }\end{array}$ & $\begin{array}{l}\text { Recognize phosphoantigens produced } \\
\text { by various microbes and transformed } \\
\text { host cells in an } \\
\text { MHC-independent manner } \\
\text { and induce cytotoxicity [1]. } \\
\text { Promote Th1 response by IFN- } \gamma \text { and } \\
\text { TNF- } \alpha \text { production [13]. } \\
\text { Produce chemokines CCL-4 and CCL-5, } \\
\text { which block HIV co-receptor CCR-5 [18]. } \\
\text { Modulate B cell and DC maturation [19]. } \\
\text { Enhance NK cell cytotoxicity via CD137 } \\
\text { Interaction [20]. } \\
\text { Antibody-dependent cellular } \\
\text { Cytotoxicity [18]. }\end{array}$ & $\begin{array}{l}\text { Function through cognate } \\
\text { interaction with HLA-A2 } \\
\text { and CD1d [7]. } \\
\text { Expand in peripheral blood of } \\
\text { renal and stem cell transplant } \\
\text { recipients with CMV } \\
\text { reactivation } \\
\text { and B cell chronic lymphocytic } \\
\text { leukemia [9]. } \\
\text { Modulate B cell and DC } \\
\text { maturation }[10,11] \text {. }\end{array}$ \\
\hline
\end{tabular}

$\gamma \delta \mathrm{T}$ cells can also be categorized into different subgroups based on their functional characteristics, which include the Th1-like IFN- $\gamma$ producing subset, the IL-17 producing cells, and those which 
function as regulatory $\gamma \delta \mathrm{T}$ cells. Human peripheral blood $\gamma \delta \mathrm{T}$ cells activated with isopentenyl pyrophosphate (IPP) can be differentiated into Th1-like cells by culturing them in the presence of recombinant (r)IL-12p70 and anti-IL-4 blocking antibodies [13]. Conversely, $\gamma \delta \mathrm{T}$ cells cultured in the presence of rIL-4 and anti-IL-12 blocking antibodies differentiate into Th2-like cells [13].

\section{Ligand Recognition by $\gamma \delta \mathrm{T}$ Cells}

Although $\gamma \delta$ TCRs are less diverse than $\alpha \beta$ TCRs, they recognize a plethora of molecules such as non-peptidic metabolites of isoprenoid biosynthesis, stress molecules (MICA and MICB), heat-shock proteins, and others (Figure 1) [21]. Recognition of these molecules allows them to respond to many microbial components, as well as transformed and infected host cells, by inducing direct cytotoxicity and rapid secretion of inflammatory chemokines and cytokines [22]. The various ligands recognized by $\gamma \delta \mathrm{T}$ cells are explored in detail below.

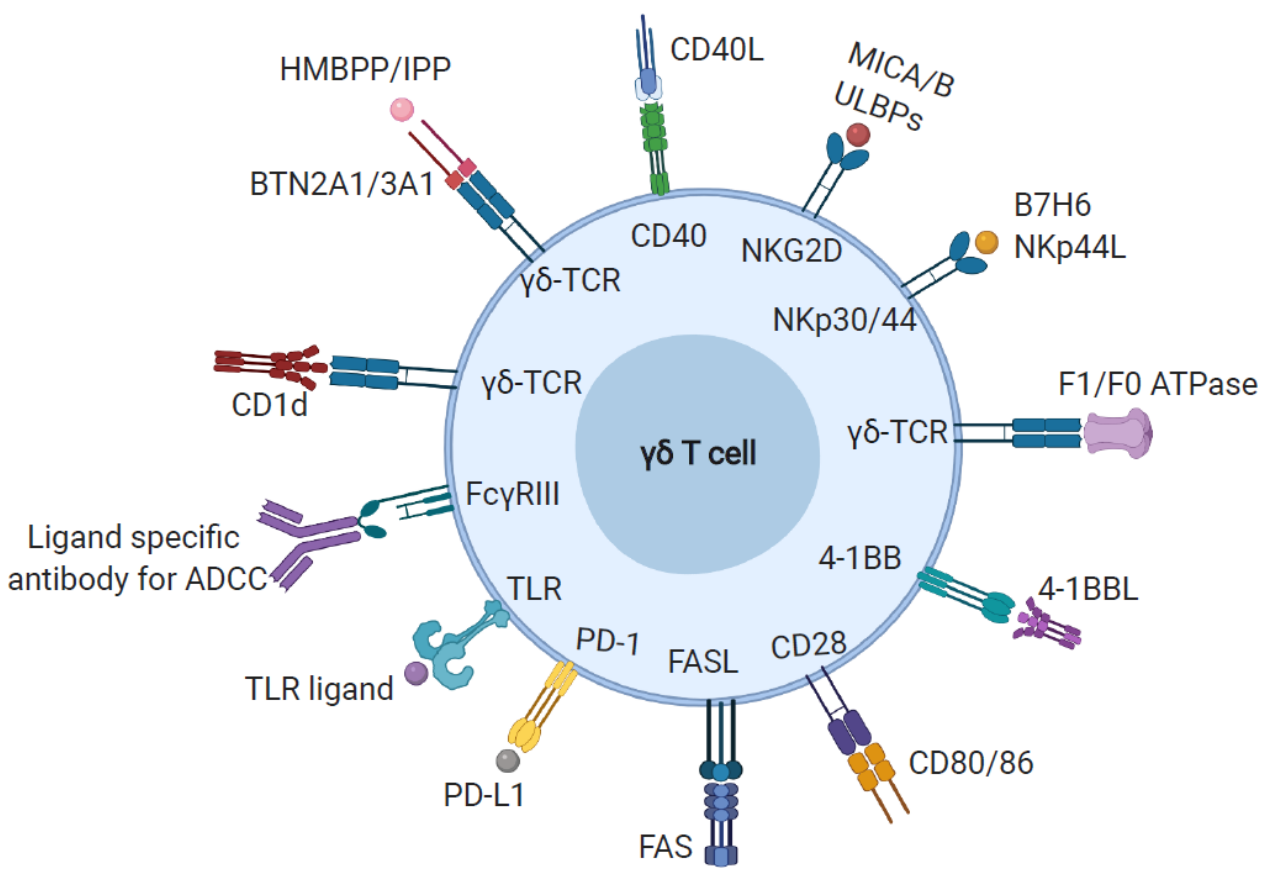

Figure 1. Ligand recognition by gamma delta $(\gamma \delta)$ T cells. $\gamma \delta$ T cells provide a wide range of immunologic functions, recognizing a diverse array of self- and non-self-ligands through their expression of various signaling receptors (depicted in the figure). Abbreviations: HMBPP: (E)-4-Hydroxy-3-methyl-but-2-enyl pyrophosphate, IPP: Isopentenyl pyrophosphate, BTN2A1: Butyrophilin 2A1, ADCC: Antibody-dependent cell-mediated cytotoxicity, TLR: Toll-like receptor, PD1: Programmed cell death protein 1, MICA/B: MHC class I chain-related protein A/B, ULBP- UL16 binding protein, NKG2D: Natural killer group 2D.

\subsection{Phosphoantigen}

The breadth and variety of antigens that $\gamma \delta$ T cells are specifically capable of recognizing have yet to be completely defined. However, their capacity to recognize non-peptidic antigens (Ag) has been studied in great depth. The predominant circulating $\mathrm{V} \gamma 9 \mathrm{~V} \delta 2 \mathrm{~T}$ cells, which contribute to $90-95 \%$ of the total $\gamma \delta \mathrm{T}$ cells in human peripheral blood, recognize phosphorylated isoprenoid precursors, collectively called phosphoantigens (pAg) [23]. The most-studied pAg in prokaryotes is (E)-4-Hydroxy-3-methyl-but-2-enyl pyrophosphate (HMBPP), an intermediate of the 2-C-methyl-d-erythritol 4-phosphate (MEP) pathway, and in eukaryotes it is IPP, an intermediate of the mevalonate pathway [23]. Besides microbial activation of $\gamma \delta \mathrm{T}$ cells, pAg that accumulates in transformed cells can also trigger $\gamma \delta$ T cell activation [24]. In contrast to $\alpha \beta$ T cells, which recognize peptide antigens presented on MHC molecules, $\gamma \delta$ T cells recognize pAg in the context of members of the immunoglobulin superfamily members, butyrophilin 2A1 and 3A1 (BTN2A1 and BTN3A1). 
Thus, butyrophilin-mediated interaction activates the signaling of the V $\gamma 9 \mathrm{~V} \delta 2$ TCR. Specifically, BTN2A1 binds the $\mathrm{V} \gamma 9+$ domain of the TCR, whereas BTN3A1 binds the V $\delta 2$ and $\gamma$-chain regions on the opposite side of the TCR to mediate signaling [25]. Interestingly, pAg is thought to bind within the cytosolic portion of the butyrophilins, promoting allosteric changes [26]. This new understanding of BTN and the $\gamma \delta$ TCR signaling pathway may facilitate the development of future $\gamma \delta$ T cell-based immunotherapies.

\subsection{MHC-Like Ligands}

$\gamma \delta \mathrm{T}$ cells recognize cellular stress proteins and pathogen-associated molecules through their expression of several common natural killer (NK) cell receptors, including NKp30, NKp44, NKp46, and the C-type lectin-like receptors NKG2D, NKG2A, and NKG2C. Specifically, V81 T cells recognize the MHC-like molecules CD1a, b, c, and d that present lipid Ags (glycolipids and certain microbial lipids) and are primarily expressed on professional Ag-presenting cells [27]. Tissue-resident V $\delta 1 \mathrm{~T}$ cells demonstrate reactivity to these ligands by producing several effector proteins, including IFN- $\gamma$ and granulysin. $\gamma \delta \mathrm{T}$ cells also maintain epithelial tissue integrity by recognizing stress-induced MHC class I-related molecules MICA and MICB in an MHC-independent fashion [28].

\subsection{Other Cell Surface and Soluble Proteins}

Besides phosphoantigens, $\gamma \delta \mathrm{T}$ cells also recognize the mitochondrial F1/F0-ATPase-related structure expressed on the Burkitt's lymphoma cell line, Daudi [29]. Several bacterial proteins can elicit $\gamma \delta \mathrm{T}$ cell responses, including staphylococcal enterotoxin A [30], toxin listeriosis O [31], tetanus toxoid from Clostridium tetani [32], and the highly virulent and immunogenic protein of Mycobacterium tuberculosis (Mtb) ESAT-6 [33]. $\gamma \delta$ T cells can also express co-stimulatory molecules, including the tumor necrosis factor (TNF) receptor family molecules CD27, CD30, CD137 (4-1BB), and inhibitory receptors such as CD279 (PD-1), to contribute to the activation and regulation of innate and adaptive immune responses [34,35]. Moreover, V $22 \mathrm{~T}$ cells express CD16 (Fc $\gamma$ receptor), which can facilitate antibody-mediated cellular cytotoxicity (ADCC) activity [36,37].

\section{4. $\gamma \delta$ T Cell Interaction with Other Immune Cells}

In addition to their ability to recognize microbial and cellular stress ligands to carry out their direct effector functions, $\gamma \delta$ T cells play an integral role in the immune system in part through their extensive crosstalk and intercellular communication activities with other immune cells (Figure 2).

\section{1. $\gamma \delta$ and NK Cells}

Crosstalk between NK cells with $\gamma \delta$ T cells not only impacts innate immune function, it also greatly influences the quality, nature, and outcome of subsequent adaptive immune responses [38-40]. Bisphosphonates, such as the FDA-approved drug zoledronate, can activate $\gamma \delta \mathrm{T}$ cells. NK cells interact with CD137 expressed on activated $\gamma \delta$ T cells, resulting in the upregulation of the cytotoxic receptor NKG2D on NK cells, enhancing their capacity to recognize and kill tumors that are usually resistant to NK cytolysis [20]. In Listeria monocytogenes-infected mice, $\gamma \delta \mathrm{T}$ cells produce IFN- $\gamma$ early during the infection, aiding in the NK cell's capacity to mount effective innate immune responses against the intracellular pathogen [41]. It is now accepted that $\gamma \delta$ T cells play an essential role in regulating NK cell-mediated immunity and that the absence of or dysfunction of $\gamma \delta$ T cells can impair NK cell activation and function [42].

\section{2. $\gamma \delta$ and $B$ Cells}

$\gamma \delta \mathrm{T}$ cells play a critical role in promoting B cell maturation, antigen presentation, and antibody production, thus greatly impacting humoral immunity [43]. Activated $\gamma \delta \mathrm{T}$ cells can produce a variety of chemokines, including CXC-chemokine ligand 13 (CXCL13), a critical factor involved in B cell 
arrangement and their interaction with follicular $\mathrm{T}$ helper cells within lymphoid tissue, as well as germinal center formation [44]. While $\alpha \beta$ T cells are also important for the germinal center formation and B cell production of immunoglobulins ( $\left.\mathrm{Ig}^{\prime} \mathrm{s}\right)$, mice deficient in TCR $\alpha$ can efficiently develop normal lymph node germinal centers and maintain the capacity to produce $\operatorname{Ig}^{\prime}$ s, suggesting that $\gamma \delta \mathrm{T}$ cells play a role in providing help to support B cell function [45]. In vitro studies have demonstrated that $\gamma \delta \mathrm{T}$ cells in the presence of IL-4 can induce B cell activation, Ig isotype switching, and secretion of $\operatorname{IgE}$ [46]. Co-culturing V $83 \mathrm{~T}$ cells and B cells results in B cell maturation, characterized by upregulation of CD40, CD86, and HLA-DR surface expression on both cell types [10]. This suggests that similar to V $82 \mathrm{~T}$ cells, V83 T cells can induce B cell maturation and differentiation into functional antigen presenting cells (APCs) capable of activating conventional T cells [19].

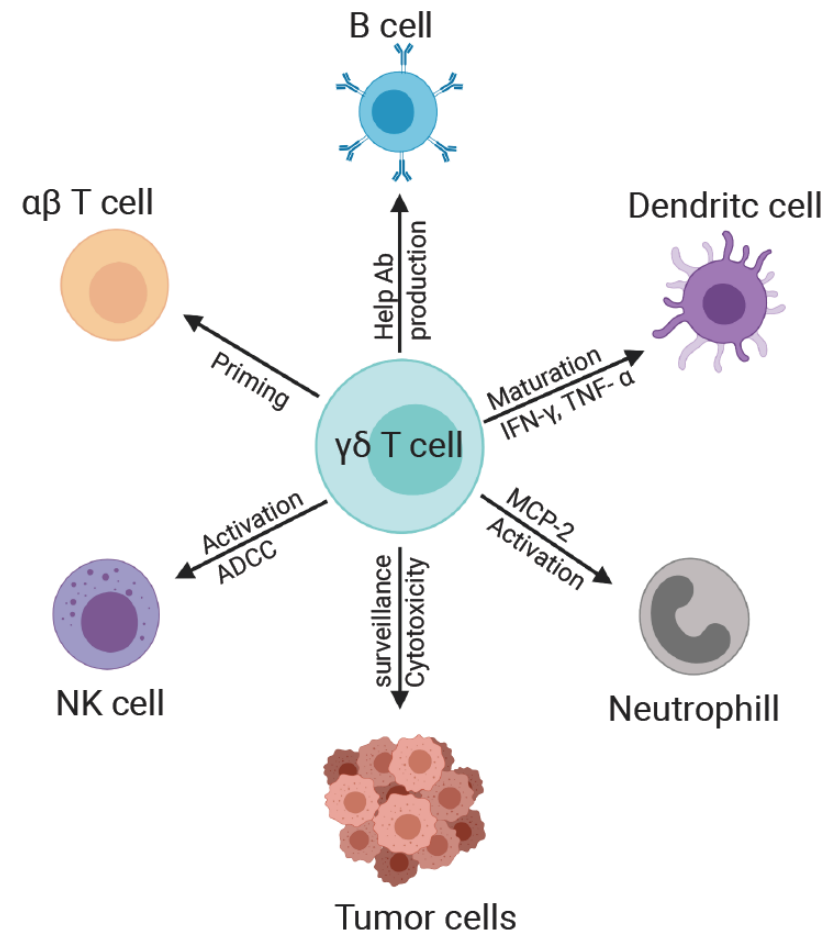

Figure 2. Crosstalk of $\gamma \delta$ T cells with other immune cells. Dendritic cell: Activated $\gamma \delta$ T cells secrete IFN- $\gamma$ and TNF- $\alpha$, which promote upregulation of CD86 and MHC class I molecules on DCs and increase DC secretion of IL-12p70. B cell: $\gamma \delta$ T cells secrete IL-4, IL-10, and CXCL13, providing help to B cells for antibody production. Neutrophil: $\gamma \delta$ T cells secrete IL-17A and CXCL8, which recruit neutrophils to inflammatory sites. NK cell: $\gamma \delta$ T cells provide NK cells with the costimulatory signal CD137L to promote their activation and enhanced cytolytic activity. $\alpha \beta$ T cell: Activated $\gamma \delta \mathrm{T}$ cells can process soluble antigens and present them in the context of both MHC class I and Class II molecules to naïve CD8+ and CD4+ $\alpha \beta$ T cells respectively, to drive their proliferation, and differentiation. Tumor cells: $\gamma \delta$ T cells can provide immunosurveillance and direct cytotoxicity of tumor cells.

\section{3. $\gamma \delta$ and Monocyte/Macrophages}

Monocytes and $\gamma \delta$ T cells are rapidly recruited to the sites of infection or inflammation, and they affect each other's ability to effectively eliminate infected cells $[47,48]$. Microbe-activated V $\gamma 9 \mathrm{~V} \delta 2$ $T$ cells can drive the differentiation of monocytes into inflammatory DCs, promoting their antigen presentation capacity and inflammatory cytokine production [47]. Notably, the activation process is bidirectional, with increased cytotoxic activity and migration of $\gamma \delta \mathrm{T}$ cells occurring when they are exposed to monocytes or macrophages infected with pathogens, such as M. tuberculosis (Mtb) [48,49]. $\gamma \delta$ T cells expanded in culture with the use of pAgs display potent cytotoxic activity against influenza virus-infected macrophages and promote viral clearance [50]. Moreover, in later stages of malaria 
infection, a $\gamma \delta \mathrm{T}$ cell subset producing M-CSF, CCL3, and CCL5, has been shown to be particularly important for acting on myeloid cells to prevent parasitemic recurrence [51].

\section{4. $\gamma \delta$ and Dendritic Cells}

$\gamma \delta \mathrm{T}$ cells interact with DCs to induce their maturation in vitro [52], characterized by the upregulation of MHC molecules and co-stimulatory molecules, such as HLA-DR, CD86, and CD83 on DCs. DC maturation is contact-independent and predominantly driven by TNF- $\alpha$ secreted from activated $\gamma \delta$ T cells. Phosphoantigen-mediated activation of $\gamma \delta$ T cells induces IL-12p70 production by DC, which in turn is critical for driving the differentiation of naïve $\alpha \beta$ T cells into IFN- $\gamma$-producing effector cells $[52,53]$. Besides V $82 \mathrm{~T}$ cells, V $81 \mathrm{~T}$ cells can also induce DC maturation. Tissue-resident V $\delta 1 \mathrm{~T}$ cells, interacting with CD1a, $b$, and c molecules expressed on immature DCs, promotes DC maturation [54]. Early during microbial infection, when there are no apparent microbe-specific CD8 T cells, these V $\delta 1 \mathrm{~T}$ cells can induce maturation of DCs and enhance their ability to present antigens to naïve CD4+ T cells. $\gamma \delta \mathrm{T}$ cells produce a large quantity of IFN $-\gamma$ early during TB infection, which helps DCs to prime antigen specific CD8 T cells, generating protection against TB infection [55]. Recent studies suggest that human V $\delta 3 \mathrm{~T}$ cells are also capable of influencing DC maturation and cytokine production [19].

\section{5. $\gamma \delta$ T and $\alpha \beta$ T Cells}

In addition to producing cytokines and chemokines, human $\gamma \delta \mathrm{T}$ cells can impact $\alpha \beta \mathrm{T}$ cell function by acting as potent antigen-presenting cells [56]. While $\mathrm{V} \gamma 9 \mathrm{~V} \delta 2 \mathrm{~T}$ cells predominantly circulate in peripheral blood, following their activation they can express MHC class I and class II molecules, the co-stimulatory molecules CD80 and CD86, and the lymph node homing CC-chemokine receptor 7 (CCR7) [56]. Furthermore, activated human $\gamma \delta \mathrm{T}$ cells can process and present soluble antigens in the context of both MHC class I and Class II to naïve CD8+ and CD4+ $\alpha \beta$ T cells respectively, to drive their activation and differentiation $[57,58]$.

Although precise mechanisms of their antigen uptake have not been well described, Seino et al. demonstrated that activated $\gamma \delta \mathrm{T}$ cells can phagocytose apoptotic cells and tumor antigens, possibly utilizing

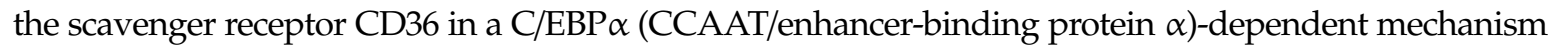
and mount a tumor antigen-specific CD8+ T cell response [59]. Recently, Wang et al. demonstrated that exosomes isolated from allogeneic $\mathrm{V} \delta 2$ cells displayed impressive antitumor activity against EBV-associated tumors in humanized mice [60]. These V 82 -derived exosomes were shown to increase the infiltration of $\alpha \beta$ T cells and induced robust CD4+ and CD8+ T cell-mediated antitumor immunity. This fact highlights their therapeutic potential to initiate antigen-specific adaptive responses against various pathogens.

\section{5. $\gamma \delta$ T Cells in HIV-1 Infection}

While $\gamma \delta \mathrm{T}$ cells have been described to provide protective immunity against tumors of epithelial [14,15] and hematological origin [61,62], they have also been explored in the setting of various chronic viral $[16,18,63-65]$ and bacterial diseases $[66,67]$, as well as malaria $[68,69]$. Furthermore, $\gamma \delta \mathrm{T}$ cells contribute to the pathogenesis and regulation of autoimmune diseases, including rheumatoid arthritis and psoriasis [70,71]. For the remainder of this paper, we have chosen to focus our attention on the function of these cells in the setting of chronic HIV-1 infection, and to shed some light on the immunotherapeutic potential of $\gamma \delta$ T cells for the treatment of HIV/AIDS.

\subsection{Impact of HIV on $\gamma \delta T$ Cells}

In healthy individuals, $\mathrm{V} \gamma 9 \mathrm{~V} \delta 2 \mathrm{~T}$ cells contribute to $90-95 \%$ of the total $\gamma \delta$ population in the peripheral blood, and the remaining $5-10 \%$ are V $\delta 2^{\text {neg }}$, such as V $\delta 1$ and V83s [72]. In HIV-infected individuals, $\mathrm{V} \gamma 9 \mathrm{~V} \delta 2 \mathrm{~T}$ cells are drastically depleted, and the $\mathrm{V} \delta 2: \mathrm{V} \delta 1$ ratio is inverted in peripheral blood [72]. Interestingly, $\mathrm{V} \gamma 9 \mathrm{~V} \delta 2$ cell depletion occurs very early during the infection, and correlates 
with viral load and CD4+ T cell depletion [73]. HIV preferentially depletes phosphoantigen responsive $\mathrm{V} \gamma 9 \mathrm{~V} \delta 2$ cells with $\mathrm{V} \gamma 9 \mathrm{~J}-\mathrm{J} \gamma 1.2 \mathrm{TCR}$ rearrangement [74]. Although the precise mechanism of depletion of V $\delta 2$ cells in HIV-infected individuals is not understood, some studies indicate that $\alpha 4 \beta 7$ and CCR5 receptors form a complex on V $\gamma 9 \mathrm{~V} \delta 2$ cells, which facilitates the binding of the bV3 loop of HIV gp120 to CCR5 in the absence of expression of the CD4 co-receptor. This interaction leads to p38 kinase activation and induces apoptosis in these cells [75]. Additionally, HIV infection leads to loss of Th17 CD4+ T cells, important for maintaining epithelial barrier integrity in the gut [76]. Depletion results in dysregulation of mucosal immunity and allows microbial translocation into the circulation, resulting in systemic immune activation [77] and expansion of V $\delta 1$ cell numbers in viremic patients [78]. Moreover, the $\mathrm{V} \gamma 9 \mathrm{~V} \delta 2$ subset from HIV-infected individuals fails to proliferate or produce cytokines in response to mycobacterial infection in vitro, suggesting that $\mathrm{V} \gamma 9 \mathrm{~V} \delta 2$ cells are functionally inactive [79]. This functional anergy in residual $\mathrm{V} \gamma 9 \mathrm{~V} \delta 2$ cells is also characterized by their decrease in responsiveness to phosphoantigens and lytic activity toward the Daudi lymphoma cell line [80].

V $\delta 1$ cells are enriched in the gut mucosa, where they help in maintaining tissue homeostasis. HIV infection further increases the frequency of V $\delta 1$ cells in the mucosa, similar to the increased levels observed in peripheral blood of HIV-infected individuals [81]. Despite immunologic control of viral replication, elite controllers (EC) also display elevated levels of V $\delta 1$ cells in the gut mucosa [82]. Few studies demonstrated that HIV-mediated disruption of gut epithelial barrier leads to translocation of gut microbiota, which activate V $\delta 1 \mathrm{~T}$ cells to produce pro-inflammatory cytokines and exacerbate the chronic inflammation $[78,83]$. The increase in V $\delta 1 \mathrm{~T}$ cell numbers seen in EC strongly correlated with the gut viral load, implying that viral replication in the mucosa and disruption in the gut epithelial barrier integrity and microbial translocation may contribute to enhanced V $\delta 1 \mathrm{~T}$ cell proliferation, also along with other immune activation events and disease progression. However, further studies are needed to better understand the causation and mechanism of V81 T cell expansion in the gut during HIV infection and the net impact of this on disease progression.

\subsection{Impact of $\gamma \delta T$ Cell Perturbations on Immune Control of HIV}

As previously alluded to, much of the impact of $\gamma \delta \mathrm{T}$ cells on immune function in health and disease is mediated through their bi-directional cross-talk with other immune cells [42]. In healthy individuals, activated $\gamma \delta \mathrm{T}$ cells induce the maturation and differentiation of DCs and B cells into functional APCs, but in HIV-infected individuals, this immunomodulatory capacity of $\gamma \delta \mathrm{T}$ cells is compromised [84]. Typically, upon activation, $\mathrm{V} \gamma 9 \mathrm{~V} \delta 2 \mathrm{~T}$ cells can drive the upregulation of CD80, CD86, HLA-DR, and CD40 surface expression on APCs, enhancing their capacity to induce primary $\alpha \beta$ T cell responses [56]. HIV infection alters the ability of APCs to process and present antigens, inhibiting the ability of $\mathrm{V} \gamma 9 \mathrm{~V} \delta 2 \mathrm{~T}$ cells to effectively interact with and positively impact the phenotype and function of APCs [84].

HIV infection may also impair the APC function of $\gamma \delta \mathrm{T}$ cells and their ability to induce $\alpha \beta$ T cell responses [85]. Activated $\gamma \delta \mathrm{T}$ cells produce large quantities of chemokines, including the macrophage inflammatory protein (MIP)-1 $\alpha / C C L 3$, MIP-1 $\beta / C C L 4$, and CCL5/RANTES, which binds to, and can compete with the HIV coreceptor CCR5 to block HIV infection of the target cells. Again, alteration of $\gamma \delta$ $\mathrm{T}$ cells in HIV infection may lead to reduced protection against new infection of target cells. V82 T cells cultured in the presence of HMBPP and IL-21 express B cell-attracting chemokine CXCL13, and the CXCL13 receptor CXCR5. This promotes B cell somatic mutation, productive rearrangement, and maturation in the germinal center, thereby promoting antibody production by B cells [86-88]. Due to the loss of $\gamma \delta \mathrm{T}$ cells in HIV infected individuals, it is likely that these crucial helper functions will also be compromised.

Numerous studies have demonstrated the protective role of $\gamma \delta \mathrm{T}$ cells in inducing cytotoxicity in HIV-infected cells and controlling HIV replication $[17,50,89]$. However, $\gamma \delta$ T cells can also contribute to negative outcomes in HIV infection. $\gamma \delta \mathrm{T}$ cells from HIV-infected individuals express high levels of the inhibitory receptor TIGIT, and they are the primary inflammatory driver in ART-suppressed HIV 
infection, and they contribute to age-associated morbidity and mortality [90]. This negative outcome is particularly highlighted in respiratory conditions, where alveolar immune cell homeostasis is disrupted in HIV-infected adults, characterized by the increased infiltration of $\gamma \delta \mathrm{T}$ cells and other immune cells in broncho-alveolar lavage fluid, resulting in an enhanced susceptibility of these individuals to lower respiratory tract infections [91].

\section{3. $\gamma \delta T$ Cell Contribution to HIV Reservoirs}

Even though current ART effectively suppresses HIV replication, the integrated viral genome remains transcriptionally silent in host chromatin, representing a major challenge towards efforts to eradicate infection [92]. Resting memory CD4+ T lymphocytes have long been considered the major reservoir site for HIV [93]. However, recent studies demonstrate that other cell types can also contribute to the latent HIV reservoir, including $\gamma \delta \mathrm{T}$ cells [82].

In one study, replication-competent HIV could be obtained from highly purified V $\delta 2 \mathrm{~T}$ cells from HIV-infected people during ART, thus identifying a previously unrecognized latent HIV reservoir within $\mathrm{V} \delta 2 \mathrm{~T}$ cells at an unexpectedly high frequency [94]. Although the precise mechanism is not known, $\gamma \delta \mathrm{T}$ cells can be infected by the CXCR4-tropic laboratory clone, $\mathrm{HIV}_{\mathrm{LAI}}$ [80]. Possible mechanisms of infection include the binding of HIV envelope glycoproteins to the highly expressed CCR5/ $\alpha 4 \beta 7$ receptor on V $\gamma 9 \mathrm{~V} \delta 2 \mathrm{~T}$ cells, leading to infection through a CD4-independent pathway [75]. Alternatively, HIV infection has been shown to induce immune activation and subsequent upregulation of CD4 receptors on some $\gamma \delta \mathrm{T}$ cells, potentially making them more susceptible to HIV infection [94]. Preliminary findings from our group, utilizing a humanized mouse model, suggest that activated V $\gamma 9 \mathrm{~V} \delta 2$ cells can indeed serve as early targets for HIV infection and play a critical role in the early stages of viral dissemination [95]. Depletion of these cells during early infection would likely negatively impact immune defenses, particularly due to the important roles they serve by producing chemokines that can act as competitive inhibitors to block HIV entry and to recruit other immune effector cells to promote HIV clearance [18]. However, the increased presence and survival of activated $\gamma \delta \mathrm{T}$ cells, which can also serve as targets for HIV infection, could contribute to enhancement in viral production and rebound. This raises more questions about the role of $\gamma \delta \mathrm{T}$ cells in the initial sequelae of HIV infection and their potential contribution to the HIV reservoir.

\subsection{Impact of Anti-Retroviral Therapy on $\gamma \delta T$ Cells in HIV-Infection}

Although ART is very effective in restoring CD4+ T cell counts and suppressing the virus below detectable levels, it fails to fully restore standard frequencies of V $\gamma 9 \mathrm{~V} \delta 2 \mathrm{~T}$ cells in HIV-infected individuals [72]. Long-term ART partially restored the J $\gamma 1.2$ repertoire of the V 22 subset [74]. These V $\gamma 9 \mathrm{~V} \delta 2$ cells are highly activated [96] but are functionally compromised, with diminished cytokine production, cytotoxicity, and proliferation [97]. At the same time, expanded V $\delta 1$ levels remain stable during ART in peripheral blood and mucosal sites, and they produce pro-inflammatory cytokines and express the exhaustion molecule CD279 (PD-1) [98]. Whether long-term ART impacts the number of V $\delta 1 \mathrm{~T}$ cells and/or their activation status is not clearly understood. Studies suggest that the loss of $\mathrm{V} \gamma 9 \mathrm{~V} \delta 2$ cells in viral controllers is significantly lower than untreated or ART individuals, and that $\gamma \delta 17$ cells are highly preserved. This preserved $\gamma \delta$ population may be responsible for preventing microbial translocation and controlling chronic systemic immune activation $[99,100]$.

\section{5. $\gamma \delta T$ Cells in HIV Immunotherapy}

$\gamma \delta$ T cells are the first line of defense against many pathogens, but their number and functions are severely altered in many infectious diseases, including HIV. Despite the long-term ART, $\gamma \delta$ T cells are not reconstituted to the original frequency in HIV-infected individuals. However, in elite controllers, the $\mathrm{V} \gamma 9 \mathrm{~V} \delta 2 \mathrm{~T}$ cell numbers are maintained at normal levels, implying that immunotherapy using V $\gamma 9$ V 82 T cells might recapitulate the immune status seen with those capable of naturally controlling HIV infection [99]. Several efforts were made to develop suitable methods for activating and expanding 
$\gamma \delta \mathrm{T}$ cells in vitro and in vivo. In vitro methods involve stimulating PBMCs with bisphosphonates, such as IPP, HMBPP, and zoledronate [101]. Zoledronate blocks the metabolic conversion of IPP, allowing this phosphoantigen to accumulate until stimulatory levels are reached, resulting in the selective activation and expansion of $\mathrm{V} \gamma 9 \mathrm{~V} \delta 2 \mathrm{~T}$ cells [101]. Bisphosphonate-mediated expansion of $\gamma \delta$ $\mathrm{T}$ cells is a rapid means to generate large quantities of these cells for adoptive cell therapy. On the other hand, the delta one $\mathrm{T}$ (DOT) cell subtype of $\gamma \delta \mathrm{T}$ cells can be expanded using OKT-3 monoclonal antibody and a cytokine cocktail consisting of rIL-4, rIFN- $\gamma$, rIL-21, and rIL-1 $\beta$ [102]. A high yield of DOT cells could be obtained by treating PBMCs with Con-A and rIL-2 and rIL-4 [103]. Alternative strategies for expanding $\gamma \delta \mathrm{T}$ cells that do not respond to pAgs or N-BP involve the use of agonistic monoclonal antibodies (mAb). Using $\gamma \delta \mathrm{TCR}$-specific antibodies, low levels of expansion of V $\delta 1$ and V $\delta 2 \mathrm{~T}$ cells has been achieved, but it has not been very successful to date. However, 20.1, an agonistic Ab specific for CD277 (a member of BTN3 subfamily), mimics pAg-induced $\mathrm{V} \gamma 9 \mathrm{~V} \delta 2$ cell activation. This antibody may simulate a conformational change in the CD277 molecule to activate and expand V $\gamma 9 \mathrm{~V} \delta 2 \mathrm{~T}$ cells [104].

In vivo approaches include zoledronate and rIL-2 combination treatment (Table 2) to induce $\mathrm{V} \gamma 9 \mathrm{~V} \delta 2 \mathrm{~T}$ cell expansion and maturation [105]. Expanded $\mathrm{V} \gamma 9 \mathrm{~V} \delta 2 \mathrm{~T}$ cells belong mainly to the central memory and effector memory subgroups. Increased DC maturation and HIV-specific CD8+ T cell responses were observed in zoledronate-treated patients [105]. Very limited adverse events of zoledronate have been found, highlighting the safety of the zoledronate treatment. Moreover, the expansion of $\mathrm{V} \gamma 9 \mathrm{~V} \delta 2 \mathrm{~T}$ cells in HIV-infected patients could also improve tumor immunity and enable better control of opportunistic pathogens. However, information concerning the impact of zoledronate treatment on viral RNA and CD4+ T cell levels is lacking and should therefore be addressed in future clinical trials [105].

Specifically, in the case of HIV-infected individuals, phosphoantigen-responsive V $\gamma 9 \mathrm{~V} \delta 2 \mathrm{~T}$ cells can be recovered by supplementation with IL-18, which promotes inflammasome formation and the robust activation and expansion of V $\gamma 9 \mathrm{~V} \delta 2$ cells in vitro [106]. Differences in the capacity to recover and expand $\gamma \delta \mathrm{T}$ cells from those who initiate ART during early vs. late stages of infection might be an obstacle for their use in immunotherapy. On the other hand, $\gamma \delta \mathrm{T}$ cells from non-HIV infected individuals can be grown efficiently, and therefore have been considered for their use in allogeneic immunotherapy settings. Importantly, transplantation of allogeneic $\gamma \delta$-T cells can result in successful engraft without inducing graft-versus-host disease (GVHD), since their mechanism of antigen recognition is MHC-independent [107]. Adoptive transfer of ex-vivo-expanded $\gamma \delta \mathrm{T}$ cells in HIV-infected individuals is an attractive HIV therapeutic strategy to consider.

Table 2. HIV immunotherapy studies using V $\delta 2$ T cells.

\begin{tabular}{|c|c|c|c|}
\hline Treatment & Participant Status & Result & Reference \\
\hline $\begin{array}{l}\text { Adoptive transfer of } \\
\text { zoledronate + IL-2 } \\
\text { expanded PBMCs }\end{array}$ & $\begin{array}{l}\text { HIV infected humanized } \\
\text { mice }\end{array}$ & $\begin{array}{l}\text { No impact of V } 82 \mathrm{~T} \text { cell on HIV induced } \\
\text { CD4+ depletion or plasma viremia }\end{array}$ & [108] \\
\hline $\begin{array}{l}\text { HMBPP + IL-2 injected } \\
\text { in Macaque }\end{array}$ & SHIV infected Macaque & $\begin{array}{l}\text { Expansion and activation of } \mathrm{V} \delta 2 \mathrm{~T} \text { cell. } \\
\text { Increase in Env specific antibody but no } \\
\text { impact on viral load. }\end{array}$ & [109] \\
\hline $\begin{array}{l}\text { Pamidronate + IL-2 } \\
\text { expanded PBMCs }\end{array}$ & $\begin{array}{l}\text { Human } \\
\text { HIV + ART }\end{array}$ & $\begin{array}{l}\text { Inhibition of HIV replication in vitro. } \\
\text { PAM expanded V } 22 \mathrm{~T} \text { cells suppress p24 } \\
\text { production by infected CD } 4+\text { T cells in the } \\
\text { presence of vorinostat. }\end{array}$ & [110] \\
\hline Ex vivo $V \delta 2 T$ cells & $\begin{array}{l}\text { Human } \\
\text { HIV + ART }\end{array}$ & $\begin{array}{l}\text { CD16 activation on V } 82 \mathrm{~T} \text { cells from HIV } \\
\text { infected individuals on ART promote } \\
\text { ADCC in vitro. }\end{array}$ & [111] \\
\hline Ex vivo IPP + IL-18 & $\begin{array}{l}\text { Human } \\
\text { HIV + ART }\end{array}$ & $\begin{array}{l}\text { IL-18 improves IPP induced V } \delta 2 \text { activation, } \\
\text { proliferation, and degranulation in HIV } \\
\text { infected individuals }\end{array}$ & [106] \\
\hline
\end{tabular}


Importantly, the potential for inducing immune reconstruction syndrome (IRS) [112], a phenomenon associated with immune reconstitution and production of proinflammatory cytokines by activated $\mathrm{T}$ cells should be recognized when considering $\gamma \delta \mathrm{T}$ cells in HIV therapy. Regarding toxicity, the combined therapeutic use of bisphosphonate and IL-2 has been used with modest success in cancer patients to promote the in vivo expansion of $\gamma \delta \mathrm{T}$ cells, with relatively minor adverse effects, including fever, injection site soreness, nausea, and diarrhea, being reported [113]. However, some cancer studies reported decreased $\gamma \delta \mathrm{T}$ cell responses during extended bisphosphonate/IL-2 therapy regimens due to the development of anergy [113]. Repeated administration of bisphosphonate/IL-2 may be worth considering as a therapy for chronic HIV, but the potential for driving functional anergy in $\gamma \delta \mathrm{T}$ cells would need to be carefully evaluated. Since treating $\gamma \delta$ T cells with rapamycin (targeting both MTORC1 and MTORC2) has been shown to reduce the anergy, the inclusion of this factor as part of combination therapy may be a reasonable alternative to overcome some of the potential problems in $\gamma \delta$ T cell-based immunotherapy [114].

\section{Into the Unknown with $\gamma \delta$ T Cells}

While $\gamma \delta$ T cells play a crucial role in controlling cancer, infection, and mediating tissue homeostasis in response to injury, the underlying mechanisms are not fully understood. The specific processes used by $\gamma \delta$ T cell subsets to recognize "danger" are unique when compared to conventional $\alpha \beta$ T cells. Even with decades of ART, the frequency and function of the $\gamma \delta \mathrm{T}$ cell population do not become fully restored [115]. However, in vivo administration of zoledronate to HIV-infected individuals has been shown to improve $\gamma \delta \mathrm{T}$ cell numbers and function [105]. Importantly, a complete understanding of the therapeutic potential of this approach for controlling HIV infection has yet to be fully studied.

Increasing interest in $\gamma \delta \mathrm{T}$ cell-based immunotherapy for cancer is driving innovative and novel approaches to harness their cytotoxic potential for an HIV cure. The recent clinical success of chimeric antigen receptor (CAR) T cells in treating leukemia and lymphoma, and the use of tumor-infiltrating lymphocytes in solid tumor patients gives new hope for using similar strategies to genetically modify $\gamma \delta$ T cells to address their dysfunction during HIV infection, or to express HIV infection-specific CAR, targeting highly conserved HIV epitopes to capitalize on their natural cytotoxic capacity. Although in vitro studies have demonstrated the HIV latency clearing capacity of V $\delta 2$ cells [110], further studies are warranted to replicate these findings in vivo and to determine the exact mechanisms of their target recognition. Animal studies using such approaches as humanized mouse models or non-human primates may prove critical to addressing questions related to the in vivo potency of $\gamma \delta \mathrm{T}$ cells in targeting tissue-resident HIV reservoirs. Nevertheless, the demonstrated protective function of $\gamma \delta \mathrm{T}$ cells in the numerous preclinical studies shown to date have been encouraging. As more researchers focus their attention to better understand these specialized immune cells, increases in the "knowns" of the $\gamma \delta \mathrm{T}$ cells will surely enhance the possibilities of their "unknowns".

Author Contributions: S.B. and R.B.M. contributed to the writing and preparation of the manuscript; M.T.L. contributed to the manuscript review and editing; R.B.M. contributed to the conceptualization and supervision of the review. All authors have read and agreed to the published version of the manuscript.

Funding: This work was supported by NIH grants R21-A131763, R21AI13876, U01HL146208, and U01AI035041. M.T.L. was supported by the UPMC Hillman Cancer Center, supported in part by the National Cancer Institute (NCI) Cancer Center Support Grant P30 CA067904. Lotze was also supported by Co-PI R01CA206012, Co-PI KC180267, Co-I R01 CA236965-01A1, Co-I R01CA160417-07, Co-I R01 GM115366-05, Co-I R01 CA229275-01A.

Conflicts of Interest: The authors declare no conflict of interest, and the funders had no role in the writing of the manuscript or in the decision to publish this review.

\section{References}

1. Gu, S.; Nawrocka, W.; Adams, E.J. Sensing of Pyrophosphate Metabolites by Vgamma9Vdelta2 T-cells. Front. Immunol. 2014, 5, 688. [CrossRef] 
2. Caccamo, N.; Dieli, F.; Wesch, D.; Jomaa, H.; Eberl, M. Sex-specific phenotypical and functional differences in peripheral human V $\gamma 9 / \mathrm{V} \delta 2$ T-cells. J. Leukoc. Biol. 2006, 79, 663-666. [CrossRef]

3. Bonneville, M.; O'Brien, R.L.; Born, W.K. Gammadelta T-cell effector functions: A blend of innate programming and acquired plasticity. Nat. Rev. Immunol. 2010, 10, 467-478. [CrossRef]

4. Siegers, G.M.; Lamb, L.S., Jr. Cytotoxic and regulatory properties of circulating Vdelta1+ gammadelta T-cells: A new player on the cell therapy field? Mol. Ther. 2014, 22, 1416-1422. [CrossRef]

5. Kenna, T.; Golden-Mason, L.; Norris, S.; Hegarty, J.E.; O’Farrelly, C.; Doherty, D.G. Distinct subpopulations of gamma delta T-cells are present in normal and tumor-bearing human liver. Clin. Immunol. 2004, 113, $56-63$. [CrossRef] [PubMed]

6. Dunne, M.R.; Elliott, L.; Hussey, S.; Mahmud, N.; Kelly, J.; Doherty, D.G.; Feighery, C.F. Persistent changes in circulating and intestinal gammadelta T-cell subsets, invariant natural killer T-cells and mucosal-associated invariant T-cells in children and adults with coeliac disease. PLoS ONE 2013, 8, e76008. [CrossRef] [PubMed]

7. Allison, T.J.; Winter, C.C.; Fournie, J.J.; Bonneville, M.; Garboczi, D.N. Structure of a human gammadelta T-cell antigen receptor. Nature 2001, 411, 820-824. [CrossRef]

8. Dechanet, J.; Merville, P.; Lim, A.; Retiere, C.; Pitard, V.; Lafarge, X.; Michelson, S.; Meric, C.; Hallet, M.M.; Kourilsky, P.; et al. Implication of gammadelta T-cells in the human immune response to cytomegalovirus. J. Clin. Investig. 1999, 103, 1437-1449. [CrossRef] [PubMed]

9. Bartkowiak, J.; Kulczyck-Wojdala, D.; Blonski, J.Z.; Robak, T. Molecular diversity of gammadelta T-cells in peripheral blood from patients with B-cell chronic lymphocytic leukaemia. Neoplasma 2002, 49, 86-90.

10. Petrasca, A.; Melo, A.M.; Breen, E.P.; Doherty, D.G. Human Vdelta3(+) gammadelta T-cells induce maturation and IgM secretion by B cells. Immunol. Lett. 2018, 196, 126-134. [CrossRef]

11. Mangan, B.A.; Dunne, M.R.; O’Reilly, V.P.; Dunne, P.J.; Exley, M.A.; O'Shea, D.; Scotet, E.; Hogan, A.E.; Doherty, D.G. Cutting edge: CD1d restriction and Th1/Th2/Th17 cytokine secretion by human Vdelta3 T-cells. J. Immunol. 2013, 191, 30-34. [CrossRef] [PubMed]

12. Wang, L.; Xu, M.; Wang, C.; Zhu, L.; Hu, J.; Chen, S.; Wu, X.; Li, B.; Li, Y. The feature of distribution and clonality of TCR gamma/delta subfamilies T-cells in patients with B-cell non-Hodgkin lymphoma. J. Immunol. Res. 2014, 2014, 241246. [CrossRef] [PubMed]

13. Wesch, D.; Glatzel, A.; Kabelitz, D. Differentiation of resting human peripheral blood gamma delta T-cells toward Th1- or Th2-phenotype. Cell Immunol. 2001, 212, 110-117. [CrossRef] [PubMed]

14. Wu, P.; Wu, D.; Ni, C.; Ye, J.; Chen, W.; Hu, G.; Wang, Z.; Wang, C.; Zhang, Z.; Xia, W.; et al. $\gamma \delta T 17$ cells promote the accumulation and expansion of myeloid-derived suppressor cells in human colorectal cancer. Immunity 2014, 40, 785-800. [CrossRef] [PubMed]

15. Zocchi, M.R.; Ferrarini, M.; Rugarli, C. Selective lysis of the autologous tumor by delta TCS1+ gamma/delta+ tumor-infiltrating lymphocytes from human lung carcinomas. Eur. J. Immunol. 1990, 20, 2685-2689. [CrossRef] [PubMed]

16. Couzi, L.; Pitard, V.; Sicard, X.; Garrigue, I.; Hawchar, O.; Merville, P.; Moreau, J.F.; Déchanet-Merville, J. Antibody-dependent anti-cytomegalovirus activity of human $\gamma \delta$ T-cells expressing CD16 (Fc $\gamma$ RIIIa). Blood 2012, 119, 1418-1427. [CrossRef] [PubMed]

17. Fausther-Bovendo, H.; Wauquier, N.; Cherfils-Vicini, J.; Cremer, I.; Debré, P.; Vieillard, V. NKG2C is a major triggering receptor involved in the V[delta]1 T-cell-mediated cytotoxicity against HIV-infected CD4 T-cells. Aids 2008, 22, 217-226. [CrossRef]

18. Poonia, B.; Pauza, C.D. Gamma delta T-cells from HIV+ donors can be expanded in vitro by zoledronate/interleukin-2 to become cytotoxic effectors for antibody-dependenT-cellular cytotoxicity. Cytotherapy 2012, 14, 173-181. [CrossRef]

19. Petrasca, A.; Doherty, D.G. Human V $\delta 2(+) \gamma \delta$ T-cells Differentially Induce Maturation, Cytokine Production, and Alloreactive T-cell Stimulation by Dendritic Cells and B Cells. Front. Immunol. 2014, 5, 650. [CrossRef]

20. Maniar, A.; Zhang, X.; Lin, W.; Gastman, B.R.; Pauza, C.D.; Strome, S.E.; Chapoval, A.I. Human gammadelta T lymphocytes induce robust NK cell-mediated antitumor cytotoxicity through CD137 engagement. Blood 2010, 116, 1726-1733. [CrossRef]

21. Wu, Y.L.; Ding, Y.P.; Tanaka, Y.; Shen, L.W.; Wei, C.H.; Minato, N.; Zhang, W. gammadelta T-cells and their potential for immunotherapy. Int. J. Biol. Sci. 2014, 10, 119-135. [CrossRef] [PubMed] 
22. Lehner, T.; Mitchell, E.; Bergmeier, L.; Singh, M.; Spallek, R.; Cranage, M.; Hall, G.; Dennis, M.; Villinger, F.; Wang, Y. The role of gammadelta T-cells in generating antiviral factors and beta-chemokines in protection against mucosal simian immunodeficiency virus infection. Eur. J. Immunol. 2000, 30, 2245-2256. [CrossRef]

23. Bukowski, J.F.; Morita, C.T.; Tanaka, Y.; Bloom, B.R.; Brenner, M.B.; Band, H. V gamma 2 V delta 2 TCR-dependent recognition of non-peptide antigens and Daudi cells analyzed by TCR gene transfer. J. Immunol. 1995, 154, 998-1006. [PubMed]

24. Gober, H.J.; Kistowska, M.; Angman, L.; Jeno, P.; Mori, L.; De Libero, G. Human T-cell receptor gammadelta cells recognize endogenous mevalonate metabolites in tumor cells. J. Exp. Med. 2003, 197, 163-168. [CrossRef]

25. Rigau, M.; Ostrouska, S.; Fulford, T.S.; Johnson, D.N.; Woods, K.; Ruan, Z.; McWilliam, H.E.G.; Hudson, C.; Tutuka, C.; Wheatley, A.K.; et al. Butyrophilin 2A1 is essential for phosphoantigen reactivity by gammadelta T-cells. Science 2020, 367. [CrossRef]

26. Rhodes, D.A.; Reith, W.; Trowsdale, J. Regulation of Immunity by Butyrophilins. Annu. Rev. Immunol. 2016, 34, 151-172. [CrossRef]

27. Agea, E.; Russano, A.; Bistoni, O.; Mannucci, R.; Nicoletti, I.; Corazzi, L.; Postle, A.D.; De Libero, G.; Porcelli, S.A.; Spinozzi, F. Human CD1-restricted T-cell recognition of lipids from pollens. J. Exp. Med. 2005, 202, 295-308. [CrossRef]

28. Born, W.K.; Kemal, M.A.; O’Brien, R.L. Diversity of gammadelta T-cell antigens. Cell Mol. Immunol. 2013, 10, 13-20. [CrossRef]

29. Scotet, E.; Martinez, L.O.; Grant, E.; Barbaras, R.; Jeno, P.; Guiraud, M.; Monsarrat, B.; Saulquin, X.; Maillet, S.; Esteve, J.P.; et al. Tumor recognition following Vgamma9Vdelta2 T-cell receptor interactions with a surface F1-ATPase-related structure and apolipoprotein A-I. Immunity 2005, 22, 71-80. [CrossRef]

30. Rust, C.J.; Verreck, F.; Vietor, H.; Koning, F. Specific recognition of staphylococcal enterotoxin A by human T-cells bearing receptors with the V gamma 9 region. Nature 1990, 346, 572-574. [CrossRef]

31. Guo, Y.; Ziegler, H.K.; Safley, S.A.; Niesel, D.W.; Vaidya, S.; Klimpel, G.R. Human T-cell recognition of Listeria monocytogenes: Recognition of listeriolysin O by TcR alpha beta + and TcR gamma delta + T-cells. Infect. Immun. 1995, 63, 2288-2294. [CrossRef] [PubMed]

32. Kozbor, D.; Trinchieri, G.; Monos, D.S.; Isobe, M.; Russo, G.; Haney, J.A.; Zmijewski, C.; Croce, C.M. Human TCR-gamma+/delta+, CD8+ T lymphocytes recognize tetanus toxoid in an MHC-restricted fashion. J. Exp. Med. 1989, 169, 1847-1851. [CrossRef] [PubMed]

33. Happ, M.P.; Kubo, R.T.; Palmer, E.; Born, W.K.; O’Brien, R.L. Limited receptor repertoire in a mycobacteria-reactive subset of gamma delta T lymphocytes. Nature 1989, 342, 696-698. [CrossRef] [PubMed]

34. Gonzalez-Amaro, R.; Portales-Perez, D.P.; Baranda, L.; Moncada, B.; Toro, C.; Lopez-Briones, S.; Espitia, C.; Mancilla, R. Co-stimulatory signals increase the reactivity of gammadelta T-cells towards mycobacterial antigens. Clin. Exp. Immunol. 2000, 120, 468-475. [CrossRef]

35. Witherden, D.A.; Johnson, M.D.; Havran, W.L. Coreceptors and Their Ligands in Epithelial gammadelta T-cell Biology. Front. Immunol. 2018, 9, 731. [CrossRef]

36. Tokuyama, H.; Hagi, T.; Mattarollo, S.R.; Morley, J.; Wang, Q.; So, H.F.; Moriyasu, F.; Nieda, M.; Nicol, A.J. V gamma $9 \mathrm{~V}$ delta $2 \mathrm{~T}$-cell cytotoxicity against tumor cells is enhanced by monoclonal antibody drugs-rituximab and trastuzumab. Int. J. Cancer 2008, 122, 2526-2534. [CrossRef]

37. Seidel, U.J.; Vogt, F.; Grosse-Hovest, L.; Jung, G.; Handgretinger, R.; Lang, P. gammadelta T-cell-Mediated Antibody-Dependent Cellular Cytotoxicity with CD19 Antibodies Assessed by an Impedance-Based Label-Free Real-Time Cytotoxicity Assay. Front. Immunol. 2014, 5, 618. [CrossRef]

38. Kalinski, P.; Mailliard, R.B.; Giermasz, A.; Zeh, H.J.; Basse, P.; Bartlett, D.L.; Kirkwood, J.M.; Lotze, M.T.; Herberman, R.B. Natural killer-dendritic cell cross-talk in cancer immunotherapy. Expert Opin. Biol. Ther. 2005, 5, 1303-1315. [CrossRef]

39. Kalinski, P.; Giermasz, A.; Nakamura, Y.; Basse, P.; Storkus, W.J.; Kirkwood, J.M.; Mailliard, R.B. Helper role of NK cells during the induction of anticancer responses by dendritic cells. Mol. Immunol. 2005, 42, 535-539. [CrossRef]

40. Mailliard, R.B.; Son, Y.I.; Redlinger, R.; Coates, P.T.; Giermasz, A.; Morel, P.A.; Storkus, W.J.; Kalinski, P. Dendritic cells mediate NK cell help for Th1 and CTL responses: Two-signal requirement for the induction of NK cell helper function. J. Immunol. 2003, 171, 2366-2373. [CrossRef] 
41. Ladel, C.H.; Blum, C.; Kaufmann, S.H. Control of natural killer cell-mediated innate resistance against the intracellular pathogen Listeria monocytogenes by gamma/delta T lymphocytes. Infect. Immun. 1996, 64, 1744-1749. [CrossRef] [PubMed]

42. He, Y.; Wu, K.; Hu, Y.; Sheng, L.; Tie, R.; Wang, B.; Huang, H. gammadelta T-cell and oTher. immune cells crosstalk in cellular immunity. J. Immunol. Res. 2014, 2014, 960252. [CrossRef] [PubMed]

43. Vermijlen, D.; Ellis, P.; Langford, C.; Klein, A.; Engel, R.; Willimann, K.; Jomaa, H.; Hayday, A.C.; Eberl, M. Distinct cytokine-driven responses of activated blood gammadelta T-cells: Insights into unconventional T-cell pleiotropy. J. Immunol. 2007, 178, 4304-4314. [CrossRef] [PubMed]

44. Ansel, K.M.; Ngo, V.N.; Hyman, P.L.; Luther, S.A.; Forster, R.; Sedgwick, J.D.; Browning, J.L.; Lipp, M.; Cyster, J.G. A chemokine-driven positive feedback loop organizes lymphoid follicles. Nature 2000, 406, 309-314. [CrossRef] [PubMed]

45. Wen, L.; Pao, W.; Wong, F.S.; Peng, Q.; Craft, J.; Zheng, B.; Kelsoe, G.; Dianda, L.; Owen, M.J.; Hayday, A.C. Germinal center formation, immunoglobulin class switching, and autoantibody production driven by "non alpha/beta" T-cells. J. Exp. Med. 1996, 183, 2271-2282. [CrossRef]

46. Gascan, H.; Aversa, G.G.; Gauchat, J.F.; Van Vlasselaer, P.; Roncarolo, M.G.; Yssel, H.; Kehry, M.; Spits, H.; De Vries, J.E. Membranes of activated CD4+ T-cells expressing T-cell receptor (TcR) alpha beta or TcR gamma delta induce IgE synthesis by human B cells in the presence of interleukin-4. Eur. J. Immunol. 1992, 22, 1133-1141. [CrossRef]

47. Eberl, M.; Roberts, G.W.; Meuter, S.; Williams, J.D.; Topley, N.; Moser, B. A rapid crosstalk of human gammadelta T-cells and monocytes drives the acute inflammation in bacterial infections. PLoS Pathog. 2009, 5, e1000308. [CrossRef]

48. Miyagawa, F.; Tanaka, Y.; Yamashita, S.; Minato, N. Essential requirement of antigen presentation by monocyte lineage cells for the activation of primary human gamma delta T-cells by aminobisphosphonate antigen. J. Immunol. 2001, 166, 5508-5514. [CrossRef]

49. Ferrero, E.; Biswas, P.; Vettoretto, K.; Ferrarini, M.; Uguccioni, M.; Piali, L.; Leone, B.E.; Moser, B.; Rugarli, C.; Pardi, R. Macrophages exposed to Mycobacterium tuberculosis release chemokines able to recruit selected leucocyte subpopulations: Focus on gammadelta cells. Immunology 2003, 108, 365-374. [CrossRef]

50. Qin, G.; Mao, H.; Zheng, J.; Sia, S.F.; Liu, Y.; Chan, P.L.; Lam, K.T.; Peiris, J.S.; Lau, Y.L.; Tu, W. Phosphoantigen-expanded human gammadelta T-cells display potent cytotoxicity against monocyte-derived macrophages infected with human and avian influenza viruses. J. Infect. Dis. 2009, 200, 858-865. [CrossRef]

51. Mamedov, M.R.; Scholzen, A.; Nair, R.V.; Cumnock, K.; Kenkel, J.A.; Oliveira, J.H.M.; Trujillo, D.L.; Saligrama, N.; Zhang, Y.; Rubelt, F.; et al. A Macrophage Colony-Stimulating-Factor-Producing $\gamma \delta$ T-cell Subset Prevents Malarial Parasitemic Recurrence. Immunity 2018, 48, 350-363. [CrossRef] [PubMed]

52. Ismaili, J.; Olislagers, V.; Poupot, R.; Fournie, J.J.; Goldman, M. Human gamma delta T-cells induce dendritic cell maturation. Clin. Immunol. 2002, 103, 296-302. [CrossRef] [PubMed]

53. Rescigno, M.; Martino, M.; Sutherland, C.L.; Gold, M.R.; Ricciardi-Castagnoli, P. Dendritic cell survival and maturation are regulated by different signaling pathways. J. Exp. Med. 1998, 188, 2175-2180. [CrossRef] [PubMed]

54. Leslie, D.S.; Vincent, M.S.; Spada, F.M.; Das, H.; Sugita, M.; Morita, C.T.; Brenner, M.B. CD1-mediated gamma/delta T-cell maturation of dendritic cells. J. Exp. Med. 2002, 196, 1575-1584. [CrossRef] [PubMed]

55. Ladel, C.H.; Blum, C.; Dreher, A.; Reifenberg, K.; Kaufmann, S.H. Protective role of gamma/delta T-cells and alpha/beta T-cells in tuberculosis. Eur. J. Immunol. 1995, 25, 2877-2881. [CrossRef] [PubMed]

56. Brandes, M.; Willimann, K.; Moser, B. Professional antigen-presentation function by human gammadelta T-cells. Science 2005, 309, 264-268. [CrossRef] [PubMed]

57. Brandes, M.; Willimann, K.; Bioley, G.; Levy, N.; Eberl, M.; Luo, M.; Tampe, R.; Levy, F.; Romero, P.; Moser, B. Cross-presenting human gammadelta T-cells induce robust CD8+ alphabeta T-cell responses. Proc. Natl. Acad. Sci. USA 2009, 106, 2307-2312. [CrossRef]

58. Himoudi, N.; Morgenstern, D.A.; Yan, M.; Vernay, B.; Saraiva, L.; Wu, Y.; Cohen, C.J.; Gustafsson, K.; Anderson, J. Human $\gamma \delta$ T lymphocytes are licensed for professional antigen presentation by interaction with opsonized target cells. J. Immunol. 2012, 188, 1708-1716. [CrossRef]

59. Muto, M.; Baghdadi, M.; Maekawa, R.; Wada, H.; Seino, K. Myeloid molecular characteristics of human $\gamma \delta$ T-cells support their acquisition of tumor antigen-presenting capacity. Cancer Immunol. Immunother. 2015, 64, 941-949. [CrossRef] 
60. Wang, X.; Xiang, Z.; Liu, Y.; Huang, C.; Pei, Y.; Wang, X.; Zhi, H.; Wong, W.H.; Wei, H.; Ng, I.O.; et al. Exosomes derived from V $\delta 2-T$-cells control Epstein-Barr virus-associated tumors and induce T-cell antitumor immunity. Sci. Transl. Med. 2020, 12. [CrossRef]

61. Correia, D.V.; Fogli, M.; Hudspeth, K.; da Silva, M.G.; Mavilio, D.; Silva-Santos, B. Differentiation of human peripheral blood Vdelta1+ T-cells expressing the natural cytotoxicity receptor NKp30 for recognition of lymphoid leukemia cells. Blood 2011, 118, 992-1001. [CrossRef] [PubMed]

62. Lanca, T.; Correia, D.V.; Moita, C.F.; Raquel, H.; Neves-Costa, A.; Ferreira, C.; Ramalho, J.S.; Barata, J.T.; Moita, L.F.; Gomes, A.Q.; et al. The MHC class Ib protein ULBP1 is a nonredundant determinant of leukemia/lymphoma susceptibility to gammadelta T-cell cytotoxicity. Blood 2010, 115, 2407-2411. [CrossRef] [PubMed]

63. Halary, F.; Pitard, V.; Dlubek, D.; Krzysiek, R.; de la Salle, H.; Merville, P.; Dromer, C.; Emilie, D.; Moreau, J.F.; Dechanet-Merville, J. Shared reactivity of V\{delta\}2(neg) \{gamma\}\{delta\} T-cells against cytomegalovirus-infected cells and tumor intestinal epithelial cells. J. Exp. Med. 2005, 201, 1567-1578. [CrossRef] [PubMed]

64. Ehl, S.; Schwarz, K.; Enders, A.; Duffner, U.; Pannicke, U.; Kuhr, J.; Mascart, F.; Schmitt-Graeff, A.; Niemeyer, C.; Fisch, P. A variant of SCID with specific immune responses and predominance of gamma delta T-cells. J. Clin. Investig. 2005, 115, 3140-3148. [CrossRef] [PubMed]

65. De Paoli, P.; Gennari, D.; Martelli, P.; Basaglia, G.; Crovatto, M.; Battistin, S.; Santini, G. A subset of gamma delta lymphocytes is increased during HIV-1 infection. Clin. Exp. Immunol. 1991, 83, 187-191. [CrossRef]

66. Spencer, C.T.; Abate, G.; Sakala, I.G.; Xia, M.; Truscott, S.M.; Eickhoff, C.S.; Linn, R.; Blazevic, A.; Metkar, S.S.; Peng, G.; et al. Granzyme A produced by gamma(9)delta(2) T-cells induces human macrophages to inhibit growth of an intracellular pathogen. PLoS Pathog. 2013, 9, e1003119. [CrossRef]

67. Xi, X.; Han, X.; Li, L.; Zhao, Z. Identification of a new tuberculosis antigen recognized by gammadelta T-cell receptor. Clin. Vaccine Immunol. 2013, 20, 530-539. [CrossRef]

68. Liu, C.; Emami, S.N.; Pettersson, J.; Ranford-Cartwright, L.; Faye, I.; Parmryd, I. Vgamma9Vdelta2 T-cells proliferate in response to phosphoantigens released from erythrocytes infected with asexual and gametocyte stage Plasmodium falciparum. Cell Immunol. 2018, 334, 11-19. [CrossRef]

69. Elloso, M.M.; van der Heyde, H.C.; vande Waa, J.A.; Manning, D.D.; Weidanz, W.P. Inhibition of Plasmodium falciparum In Vitro by human gamma delta T-cells. J. Immunol. 1994, 153, 1187-1194.

70. Hu, C.; Qian, L.; Miao, Y.; Huang, Q.; Miao, P.; Wang, P.; Yu, Q.; Nie, H.; Zhang, J.; He, D.; et al. Antigen-presenting effects of effector memory Vgamma9Vdelta2 T-cells in rheumatoid arthritis. Cell Mol. Immunol. 2012, 9, 245-254. [CrossRef]

71. Cai, Y.; Shen, X.; Ding, C.; Qi, C.; Li, K.; Li, X.; Jala, V.R.; Zhang, H.G.; Wang, T.; Zheng, J.; et al. Pivotal role of dermal IL-17-producing gammadelta T-cells in skin inflammation. Immunity 2011, 35, 596-610. [CrossRef] [PubMed]

72. Poles, M.A.; Barsoum, S.; Yu, W.; Yu, J.; Sun, P.; Daly, J.; He, T.; Mehandru, S.; Talal, A.; Markowitz, M.; et al. Human immunodeficiency virus type 1 induces persistent changes in mucosal and blood gammadelta T-cells despite suppressive therapy. J. Virol. 2003, 77, 10456-10467. [CrossRef] [PubMed]

73. Li, H.; Peng, H.; Ma, P.; Ruan, Y.; Su, B.; Ding, X.; Xu, C.; Pauza, C.D.; Shao, Y. Association between Vgamma2Vdelta2 T-cells and disease progression after infection with closely related strains of HIV in China. Clin. Infect. Dis. 2008, 46, 1466-1472. [CrossRef] [PubMed]

74. Chaudhry, S.; Cairo, C.; Venturi, V.; Pauza, C.D. The gammadelta T-cell receptor repertoire is reconstituted in HIV patients after prolonged antiretroviral therapy. Aids 2013, 27, 1557-1562. [CrossRef]

75. Li, H.; Pauza, C.D. HIV envelope-mediated, CCR5/alpha4beta7-dependent killing of CD4-negative gammadelta T-cells which are lost during progression to AIDS. Blood 2011, 118, 5824-5831. [CrossRef]

76. Brenchley, J.M.; Paiardini, M.; Knox, K.S.; Asher, A.I.; Cervasi, B.; Asher, T.E.; Scheinberg, P.; Price, D.A.; Hage, C.A.; Kholi, L.M.; et al. Differential Th17 CD4 T-cell depletion in pathogenic and nonpathogenic lentiviral infections. Blood 2008, 112, 2826-2835. [CrossRef]

77. Brenchley, J.M.; Price, D.A.; Schacker, T.W.; Asher, T.E.; Silvestri, G.; Rao, S.; Kazzaz, Z.; Bornstein, E.; Lambotte, O.; Altmann, D.; et al. Microbial translocation is a cause of systemic immune activation in chronic HIV infection. Nat. Med. 2006, 12, 1365-1371. [CrossRef]

78. Li, Z.; Li, W.; Li, N.; Jiao, Y.; Chen, D.; Cui, L.; Hu, Y.; Wu, H.; He, W. gammadelta T-cells are involved in acute HIV infection and associated with AIDS progression. PLoS ONE 2014, 9, e106064. [CrossRef] 
79. Poccia, F.; Boullier, S.; Lecoeur, H.; Cochet, M.; Poquet, Y.; Colizzi, V.; Fournie, J.J.; Gougeon, M.L. Peripheral $\mathrm{V}$ gamma 9/V delta $2 \mathrm{~T}$-cell deletion and anergy to nonpeptidic mycobacterial antigens in asymptomatic HIV-1-infected persons. J. Immunol. 1996, 157, 449-461.

80. Wallace, M.; Scharko, A.M.; Pauza, C.D.; Fisch, P.; Imaoka, K.; Kawabata, S.; Fujihashi, K.; Kiyono, H.; Tanaka, Y.; Bloom, B.R.; et al. Functional gamma delta T-lymphocyte defect associated with human immunodeficiency virus infections. Mol. Med. 1997, 3, 60-71. [CrossRef]

81. Nilssen, D.E.; Müller, F.; Oktedalen, O.; Frøland, S.S.; Fausa, O.; Halstensen, T.S.; Brandtzaeg, P. Intraepithelial gamma/delta T-cells in duodenal mucosa are related to the immune state and survival time in AIDS. J. Virol. 1996, 70, 3545-3550. [CrossRef] [PubMed]

82. Imlach, S.; Leen, C.; Bell, J.E.; Simmonds, P. Phenotypic analysis of peripheral blood gammadelta T lymphocytes and their targeting by human immunodeficiency virus type 1 In Vivo. Virology 2003, 305, 415-427. [CrossRef] [PubMed]

83. Klatt, N.R.; Funderburg, N.T.; Brenchley, J.M. Microbial translocation, immune activation, and HIV disease. Trends Microbiol. 2013, 21, 6-13. [CrossRef] [PubMed]

84. Sacchi, A.; Rinaldi, A.; Tumino, N.; Casetti, R.; Agrati, C.; Turchi, F.; Bordoni, V.; Cimini, E.; Martini, F. HIV infection of monocytes-derived dendritic cells inhibits Vgamma9Vdelta2 T-cells functions. PLoS ONE 2014, 9, e111095. [CrossRef] [PubMed]

85. Poccia, F.; Battistini, L.; Cipriani, B.; Mancino, G.; Martini, F.; Gougeon, M.L.; Colizzi, V. Phosphoantigen-reactive Vgamma9Vdelta2 T lymphocytes suppress in vitro human immunodeficiency virus type 1 replication by cell-released antiviral factors including CC chemokines. J. Infect. Dis. 1999, 180, 858-861. [CrossRef]

86. Brandes, M.; Willimann, K.; Lang, A.B.; Nam, K.H.; Jin, C.; Brenner, M.B.; Morita, C.T.; Moser, B. Flexible migration program regulates gamma delta T-cell involvement in humoral immunity. Blood 2003, 102, 3693-3701. [CrossRef]

87. Bansal, R.R.; Mackay, C.R.; Moser, B.; Eberl, M. IL-21 enhances the potential of human gammadelta T-cells to provide B-cell help. Eur. J. Immunol. 2012, 42, 110-119. [CrossRef]

88. Caccamo, N.; Battistini, L.; Bonneville, M.; Poccia, F.; Fournié, J.J.; Meraviglia, S.; Borsellino, G.; Kroczek, R.A.; La Mendola, C.; Scotet, E.; et al. CXCR5 identifies a subset of Vgamma9Vdelta2 T-cells which secrete IL-4 and IL-10 and help B cells for antibody production. J. Immunol. 2006, 177, 5290-5295. [CrossRef]

89. Mingari, M.C.; Varese, P.; Bottino, C.; Melioli, G.; Moretta, A.; Moretta, L. Clonal analysis of CD4-CD8- human thymocytes expressing a T-cell receptor gamma/delta chain. Direct evidence for the de novo expression of CD8 surface antigen and of cytolytic activity against tumor targets. Eur. J. Immunol. 1988, 18, 1831-1834. [CrossRef]

90. Belkina, A.C.; Starchenko, A.; Drake, K.A.; Proctor, E.A.; Pihl, R.M.F.; Olson, A.; Lauffenburger, D.A.; Lin, N.; Snyder-Cappione, J.E. Multivariate Computational Analysis of Gamma Delta T-cell Inhibitory Receptor Signatures Reveals the Divergence of Healthy and ART-Suppressed HIV+ Aging. Front. Immunol. 2018, 9, 2783. [CrossRef]

91. Mwale, A.; Hummel, A.; Mvaya, L.; Kamng'ona, R.; Chimbayo, E.; Phiri, J.; Malamba, R.; Kankwatira, A.; Mwandumba, H.C.; Jambo, K.C. B cell, CD8 (+) T-cell and gamma delta T-cell infiltration alters alveolar immune cell homeostasis in HIV-infected Malawian adults. Wellcome Open Res. 2017, 2, 105. [CrossRef] [PubMed]

92. Stevenson, M.; Stanwick, T.L.; Dempsey, M.P.; Lamonica, C.A. HIV-1 replication is controlled at the level of T-cell activation and proviral integration. Embo J. 1990, 9, 1551-1560. [CrossRef] [PubMed]

93. Siliciano, J.D.; Kajdas, J.; Finzi, D.; Quinn, T.C.; Chadwick, K.; Margolick, J.B.; Kovacs, C.; Gange, S.J.; Siliciano, R.F. Long-term follow-up studies confirm the stability of the latent reservoir for HIV-1 in resting CD4+ T-cells. Nat. Med. 2003, 9, 727-728. [CrossRef] [PubMed]

94. Soriano-Sarabia, N.; Archin, N.M.; Bateson, R.; Dahl, N.P.; Crooks, A.M.; Kuruc, J.D.; Garrido, C.; Margolis, D.M. Peripheral Vgamma9Vdelta2 T-cells Are a Novel Reservoir of Latent HIV Infection. PLoS Pathog. 2015, 11, e1005201. [CrossRef] [PubMed]

95. Biradar, S.; Mailliard, R.B.; et al. Adoptive transfer of allogeneic expanded gamma delta T cells promotes HIV replication in a humanized mouse model. (Manuscript in preparation). 
96. Negash, M.; Tsegaye, A.; Wassie, L.; Howe, R. Phenotypic and functional heterogeneity of peripheral gammadelta T-cells in pulmonary TB and HIV patients in Addis Ababa, Ethiopia. BMC Infect. Dis. 2018, 18, 464. [CrossRef] [PubMed]

97. Cummings, J.S.; Cairo, C.; Armstrong, C.; Davis, C.E.; Pauza, C.D. Impacts of HIV infection on Vgamma2Vdelta2 T-cell phenotype and function: A mechanism for reduced tumor immunity in AIDS. J. Leukoc. Biol. 2008, 84, 371-379. [CrossRef]

98. Olson, G.S.; Moore, S.W.; Richter, J.M.; Garber, J.J.; Bowman, B.A.; Rawlings, C.A.; Flagg, M.; Corleis, B.; Kwon, D.S. Increased frequency of systemic pro-inflammatory Vdelta1(+) gammadelta T-cells in HIV elite controllers correlates with gut viral load. Sci. Rep. 2018, 8, 16471. [CrossRef]

99. Riedel, D.J.; Sajadi, M.M.; Armstrong, C.L.; Cummings, J.S.; Cairo, C.; Redfield, R.R.; Pauza, C.D. Natural viral suppressors of HIV-1 have a unique capacity to maintain gammadelta T-cells. Aids 2009, 23, 1955-1964. [CrossRef]

100. Chevalier, M.F.; Bhatnagar, N.; Didier, C.; Lopez-Gonzalez, M.; Pavie, J.; Bollens, D.; Duvivier, C.; Collias, L.; Jung, C.; Scott-Algara, D.; et al. gammadelta T-cell subsets in HIV controllers: Potential role of Tgammadelta17 cells in the regulation of chronic immune activation. Aids 2019, 33, 1283-1292. [CrossRef]

101. Roelofs, A.J.; Jauhiainen, M.; Monkkonen, H.; Rogers, M.J.; Monkkonen, J.; Thompson, K. Peripheral blood monocytes are responsible for gammadelta T-cell activation induced by zoledronic acid through accumulation of IPP/DMAPP. Br. J. Haematol. 2009, 144, 245-250. [CrossRef]

102. Almeida, A.R.; Correia, D.V.; Fernandes-Platzgummer, A.; da Silva, C.L.; da Silva, M.G.; Anjos, D.R.; Silva-Santos, B. Delta One T-cells for Immunotherapy of Chronic Lymphocytic Leukemia: Clinical-Grade Expansion/Differentiation and Preclinical Proof of Concept. Clin. Cancer Res. 2016, 22, 5795-5804. [CrossRef] [PubMed]

103. Siegers, G.M.; Dhamko, H.; Wang, X.H.; Mathieson, A.M.; Kosaka, Y.; Felizardo, T.C.; Medin, J.A.; Tohda, S.; Schueler, J.; Fisch, P.; et al. Human V $\delta 1 \gamma \delta$ T-cells expanded from peripheral blood exhibit specific cytotoxicity against B-cell chronic lymphocytic leukemia-derived cells. Cytotherapy 2011, 13, 753-764. [CrossRef] [PubMed]

104. Gu, S.; Borowska, M.T.; Boughter, C.T.; Adams, E.J. Butyrophilin3A proteins and V $\gamma 9 \mathrm{~V} \delta 2 \mathrm{~T}$-cell activation. Semin. Cell Dev. Biol. 2018, 84, 65-74. [CrossRef] [PubMed]

105. Poccia, F.; Gioia, C.; Martini, F.; Sacchi, A.; Piacentini, P.; Tempestilli, M.; Agrati, C.; Amendola, A.; Abdeddaim, A.; Vlassi, C.; et al. Zoledronic acid and interleukin-2 treatment improves immunocompetence in HIV-infected persons by activating Vgamma9Vdelta2 T-cells. Aids 2009, 23, 555-565. [CrossRef]

106. Murday, A.S.; Chaudhry, S.; Pauza, C.D. Interleukin-18 activates Vgamma9Vdelta2(+) T-cells from HIV-positive individuals: Recovering the response to phosphoantigen. Immunology 2017, 151, 385-394. [CrossRef]

107. Kawanishi, Y.; Passweg, J.; Drobyski, W.R.; Rowlings, P.; Cook-Craig, A.; Casper, J.; Pietryga, D.; Garbrecht, F.; Camitta, B.; Horowitz, M.; et al. Effect of T-cell subset dose on outcome of T-cell-depleted bone marrow transplantation. Bone Marrow Transplant. 1997, 19, 1069-1077. [CrossRef]

108. Poonia, B. Adoptive transfer of aminobisphonate-expanded Vgamma9Vdelta2+ T-cells does not control HIV replication in a humanized mouse model. Immunotherapy 2016, 8, 521-526. [CrossRef]

109. Ali, Z.; Yan, L.; Plagman, N.; Reichenberg, A.; Hintz, M.; Jomaa, H.; Villinger, F.; Chen, Z.W. Gammadelta T-cell immune manipulation during chronic phase of simian-human immunodeficiency virus infection [corrected] confers immunological benefits. J. Immunol. 2009, 183, 5407-5417. [CrossRef]

110. Garrido, C.; Clohosey, M.L.; Whitworth, C.P.; Hudgens, M.; Margolis, D.M.; Soriano-Sarabia, N. $\gamma \delta$ T-cells: An immunotherapeutic approach for HIV cure strategies. JCI Insight 2018, 3. [CrossRef]

111. He, X.; Liang, H.; Hong, K.; Li, H.; Peng, H.; Zhao, Y.; Jia, M.; Ruan, Y.; Shao, Y. The potential role of CD16+ Vgamma2Vdelta2 T-cell-mediated antibody-dependenT-cell-mediated cytotoxicity in control of HIV type 1 disease. AIDS Res. Hum. Retrovir. 2013, 29, 1562-1570. [CrossRef]

112. Wijting, I.E.A.; Wit, F.; Rokx, C.; Leyten, E.M.S.; Lowe, S.H.; Brinkman, K.; Bierman, W.F.W.; van Kasteren, M.E.E.; Postma, A.M.; Bloemen, V.C.M.; et al. Immune reconstitution inflammatory syndrome in HIV infected late presenters starting integrase inhibitor containing antiretroviral therapy. EClinicalMedicine 2019, 17, 100210. [CrossRef] [PubMed]

113. Dieli, F.; Vermijlen, D.; Fulfaro, F.; Caccamo, N.; Meraviglia, S.; Cicero, G.; Roberts, A.; Buccheri, S.; D'Asaro, M.; Gebbia, N.; et al. Targeting human \{gamma\}delta\} T-cells with zoledronate and interleukin-2 for immunotherapy of hormone-refractory prostate cancer. Cancer Res. 2007, 67, 7450-7457. [CrossRef] [PubMed] 
114. Li, H.; Pauza, C.D. Rapamycin increases the yield and effector function of human gammadelta T-cells stimulated In Vitro. Cancer Immunol. Immunother. 2011, 60, 361-370. [CrossRef] [PubMed]

115. Li, H.; Chaudhry, S.; Poonia, B.; Shao, Y.; Pauza, C.D. Depletion and dysfunction of V $\gamma 2$ V $\delta 2$ T-cells in HIV disease: Mechanisms, impacts and therapeutic implications. Cell Mol. Immunol. 2013, 10, 42-49. [CrossRef] [PubMed]

Publisher's Note: MDPI stays neutral with regard to jurisdictional claims in published maps and institutional affiliations.

(C) 2020 by the authors. Licensee MDPI, Basel, Switzerland. This article is an open access article distributed under the terms and conditions of the Creative Commons Attribution (CC BY) license (http://creativecommons.org/licenses/by/4.0/). 